\title{
Awareness, attitude and practice of family planning methods in a tertiary care hospital, Uttar Pradesh, India
}

\author{
Uruj Jahan, Kavita Verma*, Shruti Gupta, Renu Gupta, \\ Simmi Mahour, Neha Kirti, Poonam Verma
}

Department of Obstetrics and Gynecology, GSVM Medical College Kanpur, Uttar Pradesh, India

Received: 18 November 2016

Accepted: 13 December 2016

\author{
*Correspondence: \\ Dr. Kavita Verma, \\ E-mail: soni.kavita@yahoo.com
}

Copyright: (C) the author(s), publisher and licensee Medip Academy. This is an open-access article distributed under the terms of the Creative Commons Attribution Non-Commercial License, which permits unrestricted non-commercial use, distribution, and reproduction in any medium, provided the original work is properly cited.

\begin{abstract}
Background: Family planning services have the potential to improve the quality of the lives of people and their economic welfare. The objective of the study was to assess the level of awareness, attitude, and current practice of different family planning methods and to elicit reasons for couples not using any method.

Methods: A cross sectional descriptive study was done among 1050 married women of reproductive age .

Results: Most of the women were between 21-34 years of age (60.1\%) and had primary level of education (40\%).It was observed that with increase in level of education, awareness also increased $(77.7 \%)$. The most common source of information was mass media $(53.2 \%)$. Contraceptive prevalence rate was $62.9 \%$, higher than the national data as $28.5 \%$. Most of them $(93.1 \%)$ were aware of atleast one family planning method. The most commonly known were OCPs $(74.8 \%)$, condom (68.8\%) and IUCD (56.6\%). Awareness about female sterilisation (36.4\%) was more than male sterilisation (25.3\%). 62.9\% had used atleast one contraceptive method, three prevailing methods used were condom $(65.1 \%)$, OCPs $(31.8 \%)$ and IUCD $(9.09 \%)$. Reasons precluding women from practicing contraception were desire to have a child (60.5\%), lack of knowledge (42.4\%), and unbearable side effects (25.5\%). Majority (92.4\%) thought that contraceptive use was beneficial but only (27.2\%) expressed the willingness to start practicing contraception if they received more information about the subject.

Conclusions: Majority of women had optimal knowledge and favourable attitude, still there is need to educate and motivate couples to improve family planning services.
\end{abstract}

Keywords: Awareness, Contraceptive method, Education, Family planning, Kanpur, Prevalence

\section{INTRODUCTION}

Increasing population growth is a worldwide problem today and our country with a growth rate of 16 million each year is the second most populous in the world. ${ }^{1}$ People of India being multilinguistic, multireligious and multiethnic, have different levels of awareness and acceptance of methods of family planning. It is thus necessary to develop special programme to tackle the needs of different groups. The Current total fertility rate (TFR ) of Uttar Pradesh (UP) is 3.12, still lagging behind states like Kerala, AP, Tamilnadu and Gujarat. ${ }^{2}$ Expanding the number of family planning options available to women is a critical part of increasing contraceptive coverage, decreasing unintended pregnancies and reducing maternal morbidity and mortality around the globe. ${ }^{3,4}$ Use of contraceptives can prevent at least $25 \%$ of all maternal deaths by preventing unintended pregnancies and unsafe abortions and protection against HIV and STDs. ${ }^{5}$ A lack of knowledge of contraceptive methods or a source of supply, cost and poor accessibility are the barriers that exist in developing countries. 
According to Fawcett, respondents usually exhibit considerable knowledge and attitude change over time, but they do not always exhibit corresponding changes in contraceptive practice. 6 In recent years, the need for such studies to understand the factors determining the fertility and family planning acceptance and practices by particular communities has been felt, so that more specific knowledge can be gained about factors determining family planning acceptance by particular communities. This study was undertaken with the objective to assess the level of awareness, attitude and current practice of different type of family planning methods by the women of reproductive age group ,to find out association, if any, between their family planning practices and different socio-demographic variables and also to elicit reasons precluding couple to practice family planning method.

\section{METHODS}

A cross sectional descriptive study was done in the Obstetrics and Gynaecology Department of the GSVM Medical college Kanpur, Uttar Pradesh, India. The study group included 1050 married women of reproductive age group who attended family planning OPD from September 2015 to August 2016. The women were interviewed by means of predesigned well-structured questionnaire. The dependent variables were awareness, attitude, practice and preference of contraceptive methods. Independent variables were age, religion, education level, occupation, habitat, socio economical status, age at marriage, duration of married life, number of pregnancies, no. of living children, source of information. Data were analyzed using simple tabulations.

\section{RESULTS}

Total 1050 married women of reproductive age group were included in the study. Among the 1050 women in the study group, most common encountered age group was 21-34 years $631(60.1 \%)$. Most of the non-users were below 20 years (35.6\%). Majority were Hindus 750 (71.4\%) followed by Muslims 220 (20.9\%). About 164 $(74.5 \%)$ Muslim women were non-users in comparison to about 166 (22.1\%) of Hindus. Majority had primary level of education $420(40.0 \%)$. Use of contraception increased from $62.6 \%$ in the primary educated women to $69.6 \%$ in secondary and higher educated women. Majority were housewives $830(79.04 \%)$, no. of non-users were also high 291 (35.1\%) among housewives. 340 (32.4\%) were from the rural region and $710(67.6 \%)$ came from the urban region. Contraceptive non-users were high among women from rural areas $185(54.4 \%)$. Among the participants majority were belonging to upper lower class $530(50.5 \%)$. Majority of non-users were belonging to lower socio economical class 239 (68.2\%). About $793(75.5 \%)$ got married at the age of $19-25$ years and 490 $(46.6 \%)$ had 2-4 year of married life among which 390 $(37.1 \%)$ had two pregnancy. About 460 (43.8\%) had one living child. Contraceptive use was lower among women who got married before 18 years of age $75(41.9 \%)$ and best among 19-25 years age group 517 (65.2\%). Contraceptive use was high among women with more than 5 years of married life $94(72.3 \%)$ and among women with 3 or more living children 186 (77.5\%) (Table 1). Almost all, 989 (94.2\%) had heard about family planning and are aware of atleast one method of contraception 978 (93.1\%). Among the participants main source of information was mass media in $526(53.2 \%)$ of women followed by $243(24.6 \%)$ came to know about these methods through friends \& relatives. Least common source of information were health professionals 220 $(22.2 \%)$. Most of them knew that contraceptives were available in Government hospital 758 (76.6\%) and medical store $146(14.8 \%)$. According to most of the women, family planning meant for spacing of births 450 $(45.5 \%)$ and $260(26.3 \%)$ said for both spacing and limitation of births. Among temporary methods oral contraceptive pills (OCPs) 740 (74.8\%) and condom 680 $(68.8 \%)$ seemed to be most well-known followed by intrauterine contraceptive device (IUCD) 560 (56.6\%) and injectables $380(38.4 \%)$ were less known whereas 87 $(8.79 \%)$ of participants had no idea about any contraceptive method. Among the permanent methods, most of them were aware about female sterilisation 360 (36.4\%) than male sterilisation $250(25.3 \%)$ (Figure 1). The overall percentage exceeded $100 \%$ because one woman was aware of more than one method. Only 385 (36.7\%) of the women had knowledge about the non contraceptive benefits of family planning methods. 284 (73.8\%) stated contraception helps in improvement of health, $216(56.1 \%)$ knew about protection from STD/HIV and 104 (27.01\%) knew about protection against cancer (Table 2). 970 (92.4\%) women thought that family planning was beneficial and 839 (79.9\%) said that they would like to encourage their friends and relatives to use family planning. $286(27.2 \%)$ were not using contraceptive but were willing to adopt family planning in future. Among those who were willing, most wanted condom $235(82.2 \%)$ followed by oral contraceptive pills $169(59.1 \%)$, followed by intrauterine contraceptive device in 124 (43.4\%). 114 (39.9\%) chose female sterilisation and $97(33.9 \%)$ male sterilisation. 28 $(9.79 \%)$ refused to accept any method, because of fear of side effects or prohibition by their religion and 14 $(4.89 \%)$ were not able to decide (Table3).

Among the users, majority $660(62.9 \%)$ had used contraceptive methods in the past and $390(37.1 \%)$ did not use any contraceptive in past. About 430 (65.1\%) used condom and $210(31.8 \%)$ used oral contraceptive pills followed by intrauterine contraceptive device 60 (9.09\%). $30(4.55 \%)$ women had undergone tubectomy and $12(1.82 \%)$ had adopted male sterilisation (Figure 2). Majority of the women $540(81.8 \%)$ were satisfied with the use of current contraceptive method. 630(60.0\%) of the women chose the method because they found it comfortable, easy to use and easily available. In 130 $(12.4 \%)$ of women, choice of method used was decided 
by their husbands. Among the women actively practicing contraception, discontinued family planning methods due to lack of knowledge in $143(42.4 \%)$, side effects in 86 $(25.5 \%), 204(60.5 \%)$ stopped them to conceive next baby, $104(30.9 \%)$ were currently pregnant and 145
(43.01\%) gave some other reasons for discontinuation e.g. opposition by family members, against religious belief, currently puerperium, husband staying away.103(30.6\%) of women did not give valid reason for not using contraception (Table4).

Table 1: Socio-demographic correlates of use of family planning methods $(n=1050)$.

\begin{tabular}{|c|c|c|c|}
\hline Characteristics & No. $(\%)$ & User No.(\%) & Non user no.(\%) \\
\hline $\begin{array}{l}\text { Age (years) } \\
<20 \\
21-34 \\
>35\end{array}$ & $\begin{array}{l}149(14.2) \\
631(60.1) \\
270(25.7)\end{array}$ & $\begin{array}{l}96(64.4) \\
475(75.3) \\
199(73.7)\end{array}$ & $\begin{array}{l}53(35.6) \\
156(24.7) \\
71(26.3)\end{array}$ \\
\hline $\begin{array}{l}\text { Religion } \\
\text { Hindu } \\
\text { Muslim } \\
\text { Others }\end{array}$ & $\begin{array}{l}750(71.4) \\
220(20.9) \\
80(7.62)\end{array}$ & $\begin{array}{l}584(77.9) \\
56(25.5) \\
33(41.2)\end{array}$ & $\begin{array}{r}166(22.1) \\
164(74.5) \\
47(58.8)\end{array}$ \\
\hline $\begin{array}{l}\text { Educational level } \\
\text { Illiterate } \\
\text { Primary } \\
\text { Secondary } \\
\text { Graduate }\end{array}$ & $\begin{array}{l}110(10.4) \\
420(40.0) \\
260(24.8) \\
260(24.8)\end{array}$ & $\begin{array}{r}64(58.2) \\
263(62.6) \\
181(69.6) \\
202(77.7)\end{array}$ & $\begin{array}{r}46(41.8) \\
157(37.4) \\
79(30.4) \\
58(22.3)\end{array}$ \\
\hline $\begin{array}{l}\text { Occupation } \\
\text { Housewife } \\
\text { Unskilled/Skilled worker } \\
\text { Professional }\end{array}$ & $\begin{array}{l}830(79.04) \\
150(14.3) \\
70(6.67)\end{array}$ & $\begin{array}{r}539(64.9) \\
112(74.7) \\
61(87.1)\end{array}$ & $\begin{array}{r}291(35.1) \\
38(25.3) \\
09(12.9)\end{array}$ \\
\hline $\begin{array}{l}\text { Habitat } \\
\text { Rural } \\
\text { Urban }\end{array}$ & $\begin{array}{l}340(32.4) \\
710(67.6)\end{array}$ & $\begin{array}{l}155(45.6) \\
504(70.9)\end{array}$ & $\begin{array}{l}185(54.4) \\
206(29.01)\end{array}$ \\
\hline $\begin{array}{l}\text { Socioeconomic status } \\
\text { Upper } \\
\text { Middle } \\
\text { Lower middle } \\
\text { Upper lower } \\
\text { Lower }\end{array}$ & $\begin{array}{c}- \\
- \\
170(16.2) \\
530(50.5) \\
350(33.3)\end{array}$ & $\begin{array}{l}- \\
11 \overline{3}(66.5) \\
342(64.6) \\
111(31.8)\end{array}$ & $\begin{array}{l}\quad- \\
57(\overline{33.5)} \\
188(35.4) \\
239(68.2)\end{array}$ \\
\hline $\begin{array}{l}\text { Age at marriage(years) } \\
<18 \\
9-25 \\
26 \text { or above }\end{array}$ & $\begin{array}{l}179(17.1) \\
793(75.5) \\
78(7.40)\end{array}$ & $\begin{array}{l}75(41.9) \\
517(65.2) \\
26(33.3)\end{array}$ & $\begin{array}{l}104(58.1) \\
276(34.8) \\
52(66.7)\end{array}$ \\
\hline $\begin{array}{l}\text { Duration of marriage(years) } \\
<1 \\
2-4 \\
5-7 \\
>7\end{array}$ & $\begin{array}{l}280(26.7) \\
490(46.6) \\
130(12.4) \\
150(14.3)\end{array}$ & $\begin{array}{l}176(62.9) \\
202(41.2) \\
94(72.3) \\
103(68.7)\end{array}$ & $\begin{array}{l}104(37.1) \\
288(58.8) \\
36(27.7) \\
47(31.3)\end{array}$ \\
\hline $\begin{array}{l}\text { No. of pregnancy } \\
0 \\
1 \\
2 \\
\geq 3 \\
\text { No. of living children } \\
0 \\
1 \\
2 \\
\geq 3\end{array}$ & $\begin{array}{l}50(4.76) \\
290(27.6) \\
390(37.1) \\
320(30.5) \\
60(5.71) \\
460(43.8) \\
290(27.6) \\
240(22.8)\end{array}$ & $\begin{array}{l}19(38.0) \\
184(63.4) \\
210(53.8) \\
239(74.7) \\
21(35.0) \\
214(46.5) \\
186(64.1) \\
186(77.5)\end{array}$ & $\begin{array}{l}31(62.0) \\
106(36.6) \\
180(46.2) \\
81(25.3) \\
39(65.0) \\
246(53.5) \\
104(35.9) \\
54(22.5)\end{array}$ \\
\hline
\end{tabular}


Table 2: Knowledge and awareness regarding family planning methods.

\begin{tabular}{|c|c|c|}
\hline Heard about family planning $(n=1050)$ & Number & Percentage $(\%)$ \\
\hline Aware of contraception $(n=1050)$ & $\begin{array}{l}989 \\
978\end{array}$ & $\begin{array}{l}94.2 \\
93.1\end{array}$ \\
\hline $\begin{array}{l}\text { Source of information }(\mathbf{n}=\mathbf{9 8 9}) \\
\text { Media } \\
\text { Friends and relatives } \\
\text { Health professional }\end{array}$ & $\begin{array}{l}526 \\
243 \\
220\end{array}$ & $\begin{array}{l}53.2 \\
24.6 \\
22.2\end{array}$ \\
\hline $\begin{array}{l}\text { Source of availability }(\mathbf{n}=\mathbf{9 8 9}) \\
\text { Government hospital } \\
\text { Health centre } \\
\text { Private health institute } \\
\text { Medical store/pharmacy }\end{array}$ & $\begin{array}{l}758 \\
43 \\
42 \\
146\end{array}$ & $\begin{array}{l}76.6 \\
4.34 \\
4.24 \\
14.8\end{array}$ \\
\hline $\begin{array}{l}\text { Contraceptive methods known }(\mathbf{n}=\mathbf{9 8 9}) \\
\text { Oral contraceptive pills } \\
\text { Condom } \\
\text { Intrauterine contraceptive device } \\
\text { Injectables } \\
\text { * Natural methods } \\
\text { Female sterilisation } \\
\text { Male sterilisation } \\
\text { No idea }\end{array}$ & $\begin{array}{l}740 \\
680 \\
560 \\
380 \\
227 \\
360 \\
250 \\
87\end{array}$ & $\begin{array}{l}74.8 \\
68.8 \\
56.6 \\
38.4 \\
22.9 \\
36.4 \\
25.3 \\
8.79\end{array}$ \\
\hline $\begin{array}{l}\text { Concept regarding family planning }(\mathbf{n}=\mathbf{9 8 9}) \\
\text { Limitation of births } \\
\text { Spacing of births } \\
\text { Stopping births } \\
\text { Limiting and spacing of births } \\
\text { No idea }\end{array}$ & $\begin{array}{l}150 \\
450 \\
70 \\
260 \\
59\end{array}$ & $\begin{array}{l}15.2 \\
45.5 \\
7.07 \\
26.3 \\
5.97\end{array}$ \\
\hline $\begin{array}{l}\text { Knowledge of non contraceptive benefits of family } \\
\text { planning methods }(\mathbf{9 8 9}) \\
\text { Improvement of health } \\
\text { Prevention of STD/HIV } \\
\text { Protection against cancer }\end{array}$ & $\begin{array}{l}385 \\
284 \\
216 \\
104\end{array}$ & $\begin{array}{l}36.7 \\
73.8 \\
56.1 \\
27.01\end{array}$ \\
\hline
\end{tabular}

Table 3: Attitude towards family planning methods $(\mathrm{n}=1050)$.

\begin{tabular}{|l|l|l|}
\hline Use of contraceptive beneficial & Number & Percentage (\%) \\
\hline Yes & 970 & 92.4 \\
\hline No & 80 & 7.62 \\
\hline Would practice family planning or encourage a friend/ & & \\
Relative & & 79.9 \\
\hline Yes & 839 & 20.1 \\
\hline No & 211 & 27.2 \\
\hline Will you adopt family planning(If not done earlier) & 286 & \\
\hline Family planning method willing to adopt & & \\
\hline Condom & & 82.2 \\
\hline Oral contraceptive pills & 235 & 59.1 \\
\hline Intrauterine contraceptive device & 169 & 43.4 \\
\hline Injectables & 124 & 40.6 \\
\hline Female sterilisation & 116 & 39.9 \\
\hline Male sterilisation & 114 & 33.9 \\
\hline None & 97 & 9.79 \\
\hline Undecided & 28 & 4.89 \\
\hline
\end{tabular}




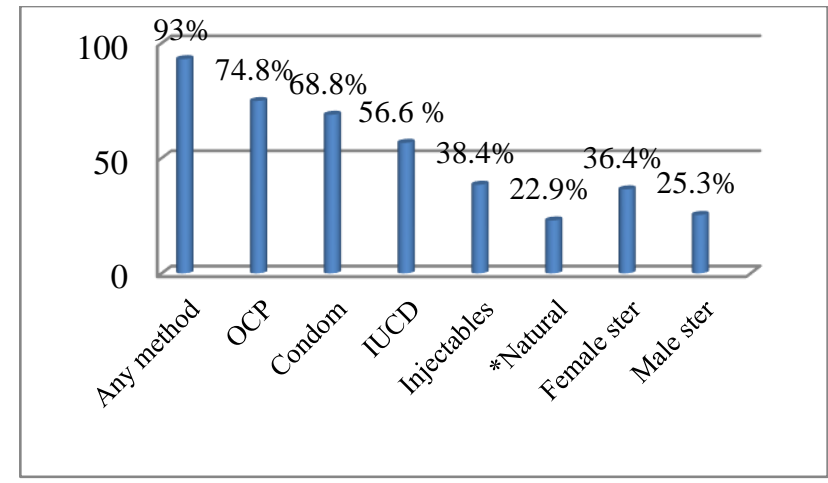

(*Natural method included: Abstinence, Basal body temperature, Calender method, Cervical mucus method, Maternal breast feeding)

Figure 1: Awareness about different types of family planning methods.

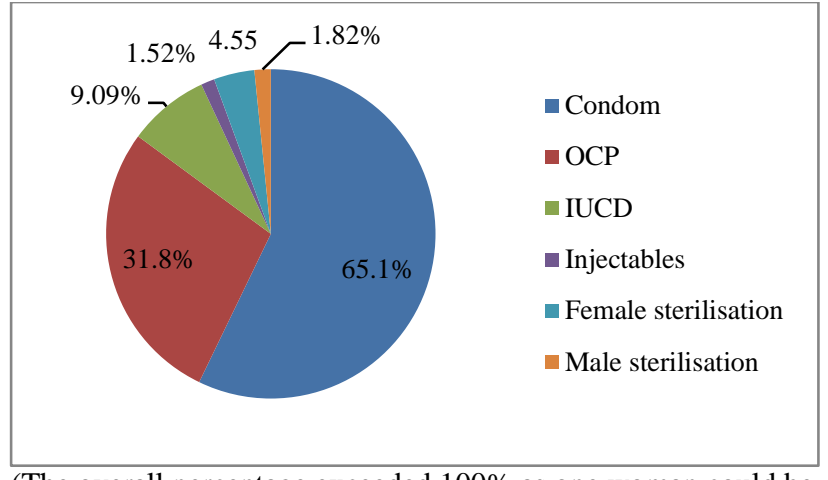

(The overall percentage exceeded $100 \%$ as one woman could be using more than one contraceptive methods)

Figure 2: Frequency of contraceptive methods used in the past.

Table 4: Practice of family planning methods $(n=1050)$.

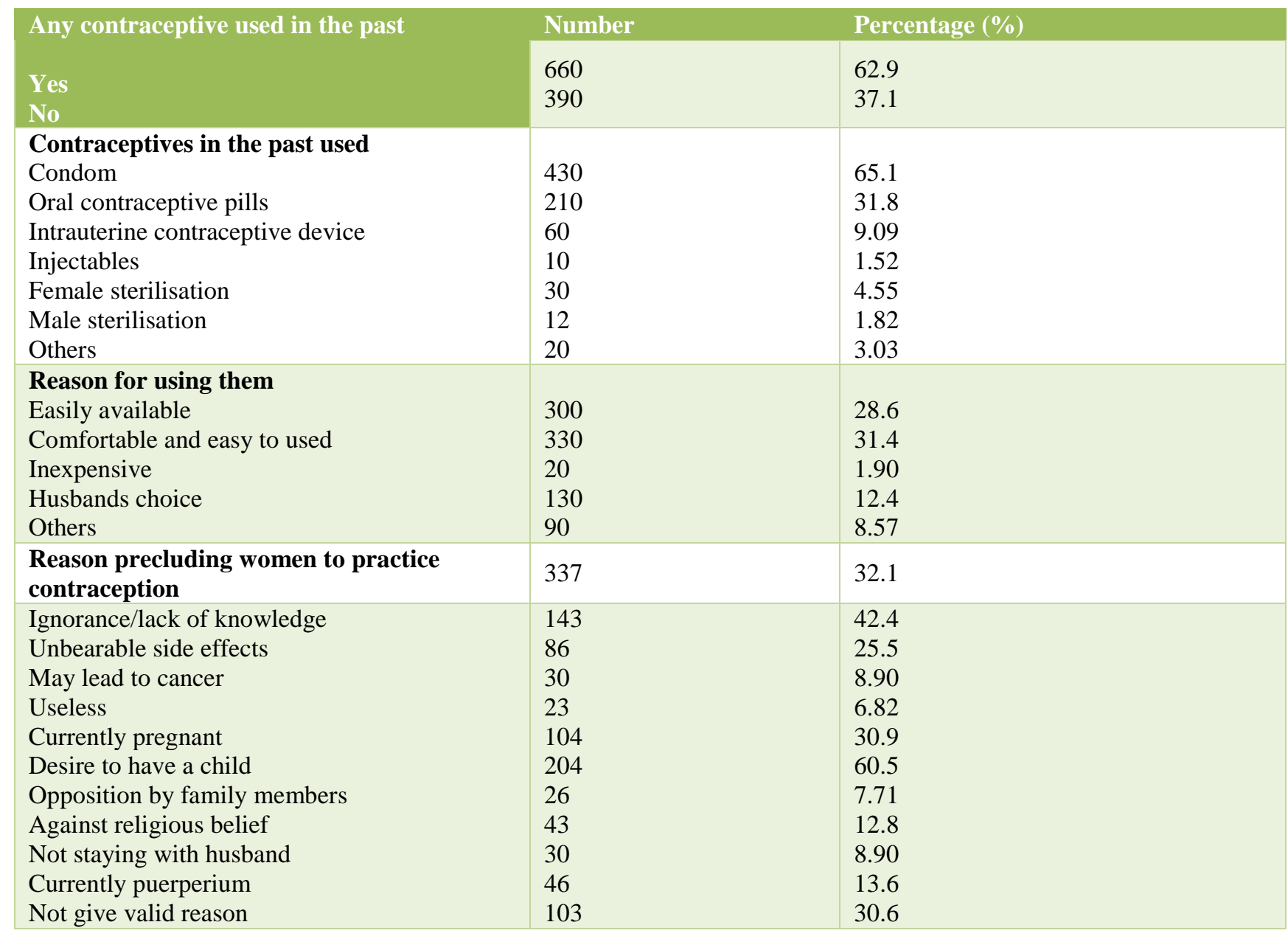

\section{DISCUSSION}

Our study showed higher contraceptive prevalence rate of $62.9 \%$ as compared to $28.5 \%$ in national study. ${ }^{7} \mathrm{~A}$ high rate of $62 \%$ was also reported in study of Sikkim.8The current prevalence of contraceptive use is thus approaching $60 \%$ worldwide, and in less developed countries, almost $53 \%$ of couple are using some form of 
contraception. ${ }^{9}$ In the present study, $60.1 \%$ were in the age group of 21-34 years, and had primary level of education $(40.0 \%)$. Maximum no. of non-users $35.6 \%$ were $<20$ years. According to Park et al, the older the women ,the more frequently they were exposed to family planning. ${ }^{10}$ Similarly in a study by Patil SS, $81.3 \%$ of non-user belong to the age group of 15-29 years. ${ }^{11}$ Also Mohanan et al in a study from Dakshina kannada concluded that majority $(52.4 \%)$, of the women using contraception were in the age group of 15-34 years. ${ }^{12} \mathrm{~A}$ survey conducted in Manipur by Donati et al concluded that Muslims had lower rates of contraceptives use (17\%) than hindus $(62 \%)$ even after controlling for education. ${ }^{13}$ This is also corroborated by our study wherein majority of users were hindus, $77.9 \%$ compared to only $25.5 \%$ Muslims. Use of contraception increased from $62.6 \%$ in the primary educated women to $69.6 \%$ in secondary and higher educated women. In their study among rural Indians, Gautam et al found that raise in education helps in improving acceptance of contraceptive devices. ${ }^{14}$ Study done by Shah also reported women's education to be a significant variable, as the use increased from $43 \%$ in the primary educated women to $70 \%$ in secondary and higher educated women. ${ }^{15}$ In our study contraceptive users were high among women from urban areas $(70.9 \%)$ in comparison to women from rural areas (45.6\%). In Pakistan DHS survey, 94\% of the currently married women residing in cities knew of atleast one modern method of contraception whereas among rural women only $71 \%$ knew of a modern method. ${ }^{16}$ There was significant association found between occupation, socioeconomical status, religion and unmet need for contraception. ${ }^{11}$ About $77.5 \%$ of women with 3 or more living children were using contraception in comparison to $35.0 \%$ by those having no living issue. Lasee et al had also shown that women with 3 or more living children are more likely to use contraception than if they had 2 or less. ${ }^{17}$

Present study revealed a high percentage of awareness of family planning methods, $93.1 \%$ of the respondents knew about atleast one method. In other studies, the percentage of awareness varied from 94\% in Pakistan, 16 94.2\% in Sikkim and even upto $100 \%$ in a study done in Bangladesh. ${ }^{18}$ In our study main source of information was mass media in $53.2 \%$ followed by friends and relatives in $24.6 \%$ and only $22.2 \%$ from health personnels. Most of the other studies also have stated print and electronic media to be the common source of public awareness, $57.7 \%$ and $50.0 \%$, whereas in Srivastava et al's study $70 \%$ had gained knowledge of contraceptive from friends and family and 39\% from television and radio..$^{9,18-20}$

Among temporary methods, $74.8 \%$ of our-subjects know about the oral contraceptives pills, $68.8 \%$ about condoms, $56.6 \%$ about IUCD, $38.4 \%$ about injectables and $22.9 \%$ about natural methods. In Srivastava et al's study IUCD was the most known $(61 \%)$ temporary method followed by OC pills $(60 \%)$ and condom $(50 \%) .{ }^{20}$ In their study
$17 \%$ were not aware of any form of contraception as against $8.79 \%$ in our study. Similarly in a study done by Renjhen et al maximum awareness was seen for oral contraceptive pills $(95.8 \%)$ followed by condom $(74.2 \%)$ and IUCD (72.0\%). ${ }^{8}$ Among permanent methods, our results showed that most of the women (36.4\%) had heard about female sterilisation as compared to only $25.3 \%$ about male sterilisation. In Sikkim also tubectomy was more well known (67.0\%) than vasectomy $(34 \%){ }^{8}$ Study done in Bangladesh similarly reported $99 \%$ of the women having knowledge of female sterilisation and only $83.0 \%$ for male sterilisation. ${ }^{18}$ This disparity may be because of general concept of laymen that reproduction is mainly the function of women. Patil SS reported unmet need for contraception was found in 59 (45.1\%) women, need for spacing in $25(19.1 \%)$ and need for limiting birth in $34(26 \%)$ women. ${ }^{11}$ This study revealed a low $(36.7 \%)$ level of knowledge of non-contraceptive benefits of family planning methods. In our study $37.1 \%$ had never used any contraceptive compared to $55 \%$ in Srivastava et al's20 study whereas $44.6 \%$ had never used any contraceptive methods in khati binita study conducted in Sikkim in $2005 .^{8}$

In our study among the users of contraceptives $62.9 \%$ patients have had used atleast any one method in the past among which $65.1 \%$ had used condom ,31.8\% had taken oral contraceptive pills while in Srivastava et al's study $34 \%$ had used condoms, $26 \%$ natural methods and only $18 \%$ oral pills. In our study $4.55 \%$ have had undergone tubectomy and $1.82 \%$ had adopted male sterilisation. ${ }^{20}$ In Pakistani study, only $16.0 \%$ of married women had used a modern method, condom was most commonly used, also proportion of female sterilisation $(4.0 \%)$ was higher than male sterilization (1\%). ${ }^{16}$ Singh et al in a study from Manipur conclude that $70 \%$ of the couples had adopted permanent family planning methods. ${ }^{21}$

$32.1 \%$ stopped using contraceptives due to various reasons like due to lack of knowledge in $42.4 \%$, side effects in $25.5 \%, 60.5 \%$ wanted to conceive next baby, another $43.01 \%$ discontinued due to various reasons like opposition by family members, husband staying away, against religious belief, currently puerperium. Side effect is the major reason for discontinuation of pills (44.0\%), IUCD $(68.0 \%)$ and injectables $(54.0 \%)$ in Sylvias's study. $^{22}$

\section{CONCLUSION}

It was observed that knowledge and awareness does not always lead to the use of contraceptives. More research is needed to understand patterns of contraceptive use, the reasons for these patterns and the effectiveness of interventions designed to enhance use. Efforts should be made to educate the public about the safety and convenience of modern, long-term, reversible methods of contraception among both healthcare professionals and the public. Family planning counselling needs to be universally included into routine antenatal clinic 
activities. Besides, improving formal female education is certain to raise the existing knowledge and also to dispel the prevailing misinformation and misperceptions about family planning methods.

\section{ACKNOWLEDGEMENTS}

Author would like to thanks Dr. Renu Gupta, Associate Professor, GSVM Medical college, Kanpur for her noble guidance and scholarly supervision, to Dr. Kavita Verma and Dr. Shruti Gupta, Lecturer, GSVM Medical College, Kanpur for their help during data collection period.

Funding: No funding sources

Conflict of interest: None declared

Ethical approval: Not required

\section{REFERENCES}

1. Park K. Park's textbook of Preventive and social Medicine. $17^{\text {th }}$ Edition. Jabalpur. Banarasidas Bhanot. 2002:325-58.

2. Vital Statistics of India, Estimates of Fertility Indicators, Census of India, Government of India. Available at http:/ /www. censusindia.gov.in /vital_statistics/ SRS_Reports_2013.html. Accessed on 14 July 2016.

3. Baveja R, Buckshee K, Das K. Evaluating contraceptive choice through the method-mix approach. An Indian council of Medical Reasearch (ICMR) task force study. Contraception. 2000;61:113-9.

4. Bongaarts J, Johansson E. Future trends in contraceptive prevalence and method mix in the developing world. Stud Fam Plann. 2002;33:24-36.

5. Weldegerima B, Denekew A. Women's knowledge, preferences and practices of modern contraceptive methods in Woreta, Ethiopia. Res Social Adm Pharm. 2008:4:302-7.

6. Fawcett JT. Psychology and population behavioural research issues in fertility and family planning. The population Council. New York. 1970.

7. Nepal Family Health Survey. Ministry of Health, New Era and Macro International, Kathmandu, Nepal and Calverton, Maryland. USA. 1996.

8. Renjhen P, Gupta SD, Barua A. A Study of knowledge, attitute and practice of family planning among the women of reproductive age group in Sikkim. J Obstet Gynecol India. 2008;58:63-7.

9. Huezo CM. Current reversible contraceptive methods: a global perspective. Int J Gynaecol Obstet. 1998;62(1):3-15.
10. Park HJ, Chung KK, Han DS. Differential effects of communication media on family planning behaviour. Korean J Prev Med. 1975;8:37-52.

11. Patil SS, Durgawale MP, Patil SR. Epidemiological correlates of unmed need for contraception in urban slum population. Al Ameen J Med Sci. 2010;3:3126.

12. Mohanan P, Kamath A, Sajjan BS. Fertility pattern and family planning practices in rural area in dakshina Kannada. Indian J Com Med. 2003;28:158.

13. Donati S, Sharma N, Medda M. Family planning knowledge attitude and practice survey in Manipure state. J Obstet Gynecol India. 2003;53:485-90.

14. Gautam AC, Seth PK. Appraisal of the knowledge, attitude and practices (KAP) of family control devices among rural Rajputs and scheduled caste of Hatwar area of Bilaspur district, Himanchal Pradesh. Anthropologist. 2001;4:289-92.

15. Shah NM. Past and current contraceptive use in Pakistan. FP. 1979;10:164-73.

16. Zafar MI, Ford N, Ankomah A. Significance of beliefs and values predicting fertility and contraceptive behaviour in Pakistan. J Biol Soc Sci. 1995;27:301-18.

17. Lasee A, Mccormic JB. Demographic and socioeconomic determinants of contraceptive use in a low income community of Karachi. J Pakistan Med Assoc. 1996;46:228-31.

18. Riley AP, Stewer MK, Chakarborty J. Programme and method related determinants of the first DMPS. Use duration in rural Bangladesh. FP. 1994;25:25567.

19. Takkar N, Geol P, Saha PK, Dua D. Contraceptive practices and awareness of emergency contraceptive in educated working women. Indian $\mathrm{J}$ Med Sci. 2005;59:143-9.

20. Srivastava R, Srivastava DK, Jina R. Contraceptive knowledge, attitude and practice survey. J Obstet Gynecol India. 2005;55:546-50.

21. Singh RKN, Devi I, Devi B. Acceptability of contraceptive methods among Urban eligible couples of Imphal, Manipur. Indian J Com Med. 2004;29:130-7.

22. Osayi S, Osemwenkha. Gender issues in contraceptive use among educated women in Edo State, Nigeria. African Health Sci. 2004;4:40-9.

Cite this article as: Jahan U, Verma K, Gupta S, Gupta R, Mahour S, Kirti N, et al. Awareness, attitude and practice of family planning methods in a tertiary care hospital, Uttar Pradesh, India. Int J Reprod Contracept Obstet Gynecol 2017;6:500-6. 